\title{
RELATIONSHIP BETWEEN SOCIAL SUPPORT AND DEPRESSION IN ELDERLY AT PANTI WERDHA MOJOPAHIT, MOJOKERTO, EAST JAVA
}

\author{
Abdillah Wahab'), Oedoyo Sudirham²) \\ 1)Doctoral Program in Public Health, Airlangga University, Indonesia \\ 2)Department of Health Promotion and Behavioral Sciences, \\ Faculty of Public Health, Airlangga University, Indonesia
}

\begin{abstract}
BACKGROUND: Depression can occur in elderly because of feeling lonely, limited physical ability, financial dependency, and lowering selfesteem. Social support may have positive impact on alleviating depression. This study aimed to determine the relationship between social support and depression in elderly.

SUBJECT AND METHODS: This was a cross sectional study, conducted in Mojokerto, East Java. A sample of 40 elderly was selected from UPT Panti Werdha Mojopahit, Mojokerto, for this study. The dependent variable was depression. The independent variable was social support, including that received from peer (friends). Spearman correlation was used to show the relationship between variables.

RESULTS: About 40\% of the elderly were lacking in social support. About 55\% had depression. There was a moderate and negative relationship between social support and depression in elderly, and it was marginally significant $(\mathrm{r}=-0.35 ; \mathrm{p}=0.061)$. The stronger social support, the less depression the elderly had.

CONCLUSION: Social support, especially from peer, as a moderate and negative relationship with depression in elderly. Strong social support can be used to alleviate depression in the elderly.
\end{abstract}

Keywords: depression, social support, peer, elderly 